\title{
MEMPROMOSIKAN BIR PLETOK SEBAGAI MINUMAN KHAS BETAWI MELALUI PENYAJIAN SEBAGAI WELCOME DRINK
}

\author{
Lila Muliani \\ Institut Ilmu Sosial dan Manajemen Stiami \\ lilamuliani@gmail.com
}

\begin{abstract}
Abstrak. Penelitian ini bertujuan untuk memperoleh gambaran konsep pariwisata berbasis kuliner lokal khas Betawi, khususnya Bir Pletok. Sebagai produk wisata, serangkaian strategi dan promosi harus dipersiapkan agar minuman tradisional yang terbuat dari ekstrak rempah menyehatkan ini layak jadi duta yang mewakili kekayaan kuliner Betawi serta memiliki standar cita rasa yang konsisten dan mutu organoleptik yang optimal. Selain itu, juga dirancang untuk membuat deskripsi dan gambaran secara faktual dan akurat mengenai fakta-fakta sejarah yang berhubungan dengan Bir Pletok sebagai salah satu kearifan lokal Betawi. Untuk seleksi terhadap produsen Bir Pletok dilakukan pada 5 wilayah administratif yaitu wilayah Jakarta Timur, Jakarta Selatan, Jakarta Barat, Jakarta Pusat, dan Jakarta Utara.

Jakarta merupakan kota yang menyandang banyak fungsi dan peran. Status sebagai kota modern dengan invasi gelombang pembangunan besar-besaran pun turut berperan melunturkan keberadaan etnis Betawi, penghuni asli kota Jakarta yang sepatutnya menyambut kehadiran para pendatang. Sebagai salah satu daerah destinasi wisata di Indonesia, cukup banyak budaya lokal Jakarta yang bisa dikembangkan dan dipromosikan, termasuk kekayaan kuliner. Ada sederet sajian lezat dan unik khas Betawi yang sangat potensial jadi daya tarik para culinary tourist, baik karena cita rasa, khasiat bagi kesehatan, atau pun nilai filosofi dan sejarah yang menyertainya. Sayangnya hingga saat ini kekayaan kuliner Betawi belum menjadi alasan bagi para wisatawan untuk datang ke Jakarta.

Hasil penelitian menunjukkan bahwa Bir Pletok sebagai bagian dari kekayaan kuliner Betawi mendapat dukungan dan apresiasi positif jika disajikan sebagai welcome drink. Pembuatan Konsentrat Bir Pletok menjadi salah satu cara yang dapat mempermudah penyimpanan dan penyajiannya sehingga lebih praktis dan efisien. Pembuatan konsentrat dengan pemekatan volume sebesar 1/4 kali dan waktu perebusan selama 60 menit dalam skala penelitian (1/2 resep), terbukti dapat menghasilkan Konsentrat Bir Pletok dengan kualitas rasa dan aroma yang tidak berbeda dari Bir Pletok segar yang tanpa pemekatan.
\end{abstract}

Kata Kunci: Bir Pletok, Welcome Drink, Minuman Betawi, dan DKI Jakarta.

Abstract. This study aims to obtain a description of the concept of local culinary-based tourism typical of Betawi, especially Pletok Beer. As a tourism product, a series of strategies and promotions should be prepared so that traditional drinks made from healthy spice extracts are worthy of being ambassadors representing Betawi culinary riches as well as having consistent standards of taste and optimal organoleptic quality. In addition, it is also designed to make factual and accurate description and description of historical facts related to Pletok Beer as one of Betawi local wisdom. The selection of Pletok Beer producers was conducted in 5 administrative areas, namely East Jakarta, South Jakarta, West Jakarta, Central Jakarta and North Jakarta.

Jakarta is a city that has many functions and roles. Status as a modern city with a massive wave of development invasion also played a role to wipe out the existence of ethnic Betawi, the native inhabitants of Jakarta who deservedly welcome the presence of the immigrants. As one of the tourist destinations in Indonesia, quite a lot of Jakarta's local culture can be developed and promoted, including culinary riches. There are a line of delicious and unique dishes that are very potent Betawi so the appeal of the culinary tourist, either because of taste, health benefits, or the 
value of philosophy and history that accompany it. Unfortunately until now the Betawi culinary wealth has not become a reason for tourists to come to Jakarta.

The results showed that Pletok Beer as a part of Betawi culinary wealth got support and positive appreciation if presented as welcome drink. Making Concentrate Beer Pletok be one way that can facilitate the storage and presentation so that more practical and efficient. Preparation of concentrate with concentration of 1/4 times and boiling time for 60 minutes in the research scale (1/2 recipe), proven to produce Pletok Beer Concentrate with taste and aroma quality that is not different from fresh Pletok beer without concentration.

Keywords: Pletok Beer, Welcome Drink, Betawi Drink, and DKI Jakarta.

\section{PENDAHULUAN}

Jakarta merupakan kota yang menyandang banyak fungsi dan peran. Selain sebagai ibukota provinsi, Jakarta juga merupakan ibukota negara. Hiruk pikuk rutinitas sebagai pusat pemerintahan, kota dagang, pusat administrasi, sentral kegiatan politik, serta pusat pendidikan, seolah tiada henti menawarkan modernitas dan 'warna baru' yang nyaris menenggelamkan identitas diri kota Jakarta. Asimilasi budaya pun tak terelakkan, apalagi sejak dulu kota Jakarta sudah menjadi melting pot. Beragam etnis lokal maupun asing memadati kota Jakarta. Status sebagai kota modern dengan invasi gelombang pembangunan besar-besaran pun turut berperan melunturkan keberadaan etnis Betawi, penghuni asli kota Jakarta yang sepatutnya menyambut kehadiran para pendatang.

Sebelum tahun 1960-an di pusat Jakarta terdapat banyak perkampungan Betawi, namun karena pembangunan dan industrialisasi, banyak orang Betawi Kota yang pindah ke pinggiran kota Jakarta (Shabab, 2004). Lahan milik warga Betawi semakin banyak yang diperjualbelikan secara bebas. Kota Jakarta pun kemudian ditinggalkan penduduk aslinya, berganti dengan para pendatang yang berlomba mencicipi indahnya metropolitan. Berkedok globalisasi, kearifanlokal tradisional Betawi kian terasa asing di kampungnya sendiri. Derasnya arus pembangunan ini, di satu sisi telah melahirkan kota Jakarta yang modern dan siap bersaing dengan kota-kota besar lain. Jakarta termasuk satu dari 3 daerah di Indonesia yang paling banyak dikunjungi wisatawan asing, selain Bali dan Batam (Hermawan, 2014). Sepanjang tahun 2013, jumlah wisatawan (nusantara dan mancanegara) yang datang ke Jakarta meningkat secara signifikan. Namun, selain karena predikat sebagai kota metropolitan, daya tarik wisata lainnya dinyatakan berasal dari sejumlah festival seni dan budaya yang diselenggarakan di Jakarta (Deny, 2014). Karena itu, selain menawarkan kehebatan kota urban yang gemerlap dengan fasilitas mewah, Jakarta sepatutnya juga lebih sering memamerkan keunikan budaya etnis Betawi, termasuk kuliner, yang sarat dengan nilai sejarah dan filosofi.

Data dari sebuah survey yang dilakukan Hilton Worldwide terhadap 2.700 wisatawan dari sembilan negara di Asia Pasifik menyatakan bahwa makanan dan minuman merupakan faktor penentu dalam memilih tujuan wisata. Sebanyak $86 \%$ wisatawan merasa wajib mencicipi makanan khas lokal saat mereka berkunjung ke suatu tempat wisata, $90 \%$ wisatawan mencari pengalaman kuliner yang unik saat mereka berkunjung ke suatu tempat wisata, dan $89 \%$ wisatawan mengatakan bahwa mereka akan kembali menunjungi sebuah tempat karena menemukan pengalaman bersantap yang memuaskan (Daneswari, 2014). Sebagai salah satu daerah destinasi wisata di Indonesia, cukup banyak budaya lokal Jakarta yang bisa dikembangkan dan dipromosikan, termasuk kekayaan kuliner. Ada sederet sajian lezat dan unik khas Betawi yang sangat potensial jadi daya tarik para culinary tourist, baik karena cita rasa, khasiat bagi kesehatan, atau pun nilai filosofi dan sejarah yang menyertainya. 
Lila Muliani, Mempromosikan Bir Pletok Sebagai Minuman Khas Betawi Melalui Penyajian...

Sayangnya hingga saat ini kekayaan kuliner Betawi belum menjadi alasan bagi para wisatawan untuk datang ke Jakarta.

Tempat makan yang representatif dan khusus menjual makanan khas Betawi di tengah kota Jakarta hingga saat ini memang belum terlalu banyak. Kalaupun ada, sajian yang dijajakan terbatas pada pilihan makanan populer seperti Nasi Uduk, Gado-Gado, Ketoprak, Kerak Telur, Asinan, dan Soto Betawi. Padahal sesungguhnya masih banyak makanan atau minuman lain yang tak kalah lezat dan layak untuk diperkenalkan kepada para wisatawan, salah satunya Bir Pletok. Bir Pletok merupakan salah satu minuman Betawi yang bisa direkomendasikan. Terbuat dari ekstrak rempah namun sama sekali tidak mengandung alkohol, walau namanya mengandung kata bir. Saat ini, mencicipinya saja masih jadi satu hal yang eksklusif, bahkan bagi warga Jakarta sekalipun. Padahal minuman pemberi efek hangat dan berwarna kemerahan akibat kontribusi kayu secang dalam komposisi bahannya ini dulu adalah minuman rakyat yang biasa dijajakan oleh pedagang keliling. Namun kepopuleran Bir Pletok kini hanya terdengar sayup-sayup.

Bir Pletok terbuat dari racikan rempah khas Indonesia. Sejak dulu rempah sudah menjadi bagian penting dalam dapur Indonesia, sebelum revolusi cita rasa Eropa abad ke- 15. Dengan demikian minuman dari ekstrak rempah ini, secara historis akan menggugah ingatan pada kejayaan rempah Indonesia masa lalu sehingga sangat pantas menjadi alternatif minuman bagi para wisatawan, baik nusantara maupun mancanegara. Jika wisatawan sudah mencicipi Bir Pletok, mengetahui khasiatnya, menyukai rasanya, maka mereka akan tertarik untuk membeli dan mencari tahu tentang produsennya. Jika ia termasuk seorang wisatawan minat khusus yang menggilai kuliner (food traveller), maka kemungkinan besar ia dan mengapresiasi cerita terkait sejarah dan budaya yang ada dibelakangnya sehingga akan tertarik untuk lebih mengeksplorasi Jakarta dan mengenal kuliner khas lainnya. Di samping cita rasanya yang khas, khasiat Bir Pletok yang menyehatkan merupakan keunggulan yang patut diperkenalkan. Berbagai jenis minuman tradisional yang berasal dari ekstrak rempah sejak dulu sudah dimanfaatkan untuk mengatasi berbagai masalah kesehatan dan sudah menjadi bagian kehidupan masyarakat Indonesia.

Dengan populernya gaya hidup sehat berkonsep kembali ke alam (back to nature), Bir Pletok makin menjadi penting untuk diperkenalkan. Tren gaya hidup sehat dunia ini dipicu oleh prevalensi penyakit kronis yang meningkat, adanya kegagalan penggunaan obat modern untuk penyakit tertentu (seperti kanker), mahalnya harga obat, dan komplikasi yang ditimbulkan dari obat sintetik serta meluasnya akses informasi mengenai obat herbal ke seluruh dunia (Syafputri, 2012). Demi mempromosikan Bir Pletok maka diperlukan sebuah cara yang lebih fokus untuk memperkenalkannya kepada para wisatawan yang datang ke Jakarta. Salah satu upaya yang bisa dilakukan adalah dengan menjadikan Bir Pletok sebagai welcome drink. Cara ini langsung menyasar pada target yang diharapkan dan secara tidak langsung dapat mempromosikan pariwisata kota Jakarta. Saat ini, penyajian minuman tradisional sebagai welcome drink sudah diaplikasikan pada beberapa hotel, terutama hotel yang mengedepankan konsep heritage Indonesia, ataupun spa tradisional. Pada Konferensi Asia Afrika (KAA) yang berlangsung April 2015 lalu, jamu juga disajikan sebagai welcome drink di 19 hotel yang menjadi tempat beristirahat para delegasi KAA di Jakarta dan Bandung. Respon yang diberikan ternyata cukup baik (Syarifani, 2015). Bahkan persediaan jamu sepanjang KAA tersebut harus terus ditambah untuk memenuhi kebutuhan para tamu (Nursalikah, 2015).

Adanya beberapa formulasi resep dan cita rasa Bir Pletok yang ada di masayarakat Betawi saat ini memerlukan tahap penyeleksian untuk memilih formulasi Bir Pletok yang paling disukai, melalui uji sensori. Terhadap Bir Pletok terpilih dan disukai ini kemudian akan dilakukan pengembangan, terutama dalam hal kepraktisan dalam penyimpanan. Saat ini pengembangan produk Bir Pletok sudah 
dilakukan melalui pembuatan Bir Pletok instan berbentuk serbuk/bubuk yang tinggal diseduh dengan air panas. Namun, proses instanisasi yang dilakukan membuat kualitas aroma dan rasanya rempahnya menurun. Karena itu diperlukan sebuah langkah pengembangan lain yang bisa mempertahankan kualitas aroma dan rasa Bir Pletok yang lebih optimum, salah satunya dengan cara pembuatan Konsentrat Bir Pletok. Berdasarkan penjelasan di atas dirumuskan masalah sebagai berikut:

1. Bagaimana cara mendapatkan rekomendasi Bir Pletok yang mewakili tiap wilayah administratif di Jakarta?

2. Dari 5 variasi Bir Pletok yang mewakili tiap wilayah adminsitratif di Jakarta, formula mana yang paling disuka dan kemudian terpilih untuk dijadikan Konsentrat Bir Pletok?

3. Bagaimana teknik yang tepat untuk memilih formula Bir Pletok yang paling disukai?

4. Bagaimana membuat Konsentrat Bir Pletok dengan kualitas (rasa dan aroma) yang tetap menjaga keauntentikan cita rasa aslinya?

5. Seberapa besar dukungan yang diberikan oleh warga Jakarta jika Bir Pletok disarankan untuk disajikan sebagai welcome drink?

6. Apa saja kajian pustaka dari khasiat Bir Pletok yang memiliki latar belakang ilmiah untuk menjadi nilai jual yang dapat meningkatkan promosi Bir Pletok sebagai salah satu daya tarik wisata kota Jakarta?

7. Apa saja nilai-nilai sejarah dan budaya yang terkait dengan asal muasal hadirnya Bir Pletok dalam budaya masyarakat Betawi yang dapat yang dapat meningkatkan promosi Bir Pletok sebagai salah satu daya tarik wisata kota Jakarta?

\section{TINJAUAN PUSTAKA}

Makanan (food) dan budaya (culture) merupakan dua hal yang tidak bisa dipisahkan. Makanan yang kita makan tidak hanya menjelaskan 'apa' tapi juga bisa menggambarkan 'siapa', 'mengapa', 'bagaimana', bahkan 'di mana' dan 'dari mana kita berasal'. Definisi budaya yang dimaksud memiliki pengertian yang lebih luas dari sekedar etnis atau suku. Budaya juga meliputi bahasa, cara berkomunikasi, value (nilai), hingga agama atau kepercayaan. Istilah cultural cuisine atau cultural foods kemudian memberikan pemahaman bahwa makanan bisa merefleksikan letak geografis, iklim, hingga sejarah dan value dari daerah asal makanan tersebut. Konsep cultural food ini menjadi dasar dari culinary tourism atau wisata kuliner yang belakangan kian marak sejalan dengan laju industri pariwisata dunia, termasuk di Indonesia, yang kecenderungannya terus meningkat.

Di Indonesia, industri pariwisata yang sempat ambruk pasca tragedi bom Bali tahun 2002, sudah kembali meningkat mulai tahun 2007. Menurut situs resmi Kementerian Pariwisata dan Ekonomi Kreatif, pertumbuhan industri pariwisata di Indonesia tahun 2014 mencapai 9,39\% lebih tinggi dari tahun sebelumnya. Angka itu di atas pertumbuhan ekonomi nasional yang mencapai $5,7 \%$. Konsep culinary tourism sepatutnya mengedepankan makanan lokal atau makanan tradisional sebagai daya tarik wisata. Menurut Inskeep (1991: 286), kualitas dan keunikan makanan menjadi faktor yang bisa mempromosikan makanan lokal. Istilah culinary tourism atau wisata kuliner pertama kali oleh Lucy Long pada tahun 1998. Wisatawan yang dikategorikan sebagai culinary tourist adalah mereka yang berwisata dengan motivasi untuk mencicipi makanan dan minuman (Wolf, 2002 dalam Karim, 2006).

Tak semua negara memiliki kesempatan menjadi target destinasi wisata kuliner yang mampu mengedepankan aspek sejarah dan budaya dari makanannya. Kanada, Australia, dan New Zealand memiliki tantangan besar dalam mengembangkan culinary tourism (Blakey, 2012). Sebagai negara yang lahir dari peleburan banyak budaya, tanpa catatan sejarah kuliner yang kaya, ketiga negara tersebut harus mampu menemukan angle lain 
Lila Muliani, Mempromosikan Bir Pletok Sebagai Minuman Khas Betawi Melalui Penyajian...

dalam mempromosikan wisata kulinernya. Sangat berbeda dengan negeri kita, Indonesia. Dengan sekitar 17.000 pulau dan lebih dari 900 etnis, artinya Indonesia memiliki lebih dari 900 kekayaan kuliner yang memiliki ciri khas dan keunikan tersendiri (Murdijati, 2014). Keberagaman ini lah yang sangat berpotensi menjadi objek menarik bagi para wisatawan. Makanan lokal bisa menjadi salah satu cara untuk mengeksplorasi budaya sebuah negara, karena makanan juga mewakili letak geografis, sejarah, dan kebiasaan masyarakat setempat. Makanan merupakan salah satu identitas dari sebuah daerah/negara, layaknya sebuah simbol daerah (Reza, 2014).

Long (1998) mendefiniskan culinary toursim sebagai eksplorasi wisatawan terhadap citarasa makanan dan kebiasaan makan daerah tertentu. Karena itulah makanan daerah setempat lokal (local cuisine/local food) menjadi salah satu poin penting dalam wisata kuliner. Bagaiamana memperkenalkan dan mempromosikan makanan/minuman lokal dengan cita rasa autentik pada para wisatawan? Itulah tantangan yang harus dihadapi.

Berdasarkan data Sensus Penduduk tahun 2000, jumlah etnis Betawi di Jakarta tinggal sekitar 27.65\%, sisanya dijejali oleh pendatang, dari etnis Jawa sekitar 35.16\% (paling tinggi), Sunda (15.27\%), Tionghoa (5.53\%), Batak (3.61\%), dan Minangkabau $(3.18 \%)$. Sisanya ada etnis Melayu, Bugis, Madura, Banten, Banjar, serta etnis lainnya. Derasnya arus pendatang yang tergiur dengan gemerlap ibu kota, globalisasi dan modernisasi, tak hanya telah mengubah pola makan etnis Betawi tapi juga membuat komunitas Betawi sedikit demi sedikit tergeser dari pusat kota. Tak heran jika kuliner Betawi pun kalah pamor dibandingkan kuliner pendatang. Baru tahun 2014 Bir Pletok menjadi salah satu kuliner Betawi yang dijadikan ikon dalam Jakarta Fair, menemani Kerak Telur yang sudah belasan tahun menjadi host tunggal di festival tahunan tersebut. Hal ini bertujuan untuk mengembalikan eksistensi Bir Pletok dalam khasanah kuliner Betawi. Bir Pletok dari Provinsi DKI Jakarta juga baru saja ditetapkan sebagai satu dari 96 Warisan Budaya Tak Benda Indonesia yang dikeluarkan oleh Kementrian Pendidikan dan Kebudayaan Republik Indonesia, pada Oktober 2014 lalu. Sayangnya kepopuleran Bir Pletok kini makin meredup. Produksinya sangat terbatas dan hanya dipasarkan secara konvensional oleh industri-industri rumah tangga dan diperuntukkan bagi kebutuhan masyarakat Betawi yang akan mengadakan suatu acara.

Awal tahun 2015 Pemerintah Provinsi DKI Jakarta sempat mengeluarkan pernyataan yang membawa angin segar untuk perkembangan kuliner Betawi, terutama Bir Pletok. Pemprov DKI rencananya akan merevisi peraturan daerah tentang minimarket dan akan mewajibkan pengelola minimarket untuk menjual produk-produk UMKM (Usaha Mikro Kecil dan Menengah) khas Jakarta, seperti Nasi Uduk atau Bir Pletok. Wacana ini sudah langsung diimplementasikan di beberapa minimarket yang menjual Bir Pletok instan dalam kemasan paper cup. Tinggal diseduh dengan air panas, Bir Pletok hangat siap dinikmati. Produk Bir Pletok instan ini merupakan produksi Alifah, sebuah UMKM produsen Bir Pletok dari Jakarta Barat. Ditilik dari definisi jamu dalam Permenkes No.003/Menkes/Per/I/2010 yang menyebutkan bahwa jamu adalah bahan atau ramuan bahan yang berupa tumbuhan, bahan hewan, bahan mineral, sediaan sarian (galenik), atau campuran dari bahan tersebut yang secara turun temurun telah digunakan untuk pengobatan, dan dapat diterapkan sesuai dengan norma yang berlaku di masyarakat, maka Bir Pletok masuk dalam kategori jamu, karena terbuat dari racikan rempah-rempah yang termasuk dalam jenis tumbuhan. Khasiat Bir Pletok pun sejak dulu juga sudah diyakini sebagai obat masuk angin, obat batuk, dan dapat mengobati masalah sulit tidur.

Dalam industri perhotelan, penyajian welcome drink atau minuman selamat datang memang bukan termasuk mandatory atau prosedur baku yang wajib dilakukan. Karena itu tidak semua hotel menyajikannya, biasanya hanya disajikan oleh hotel-hotel berbintang, dan tidak untuk hotel-hotel kecil 
atau guesthouse. Penyajian welcome drink pada dasarnya merupakan salah satu bentuk servis yang diberikan pihak hotel kepada para tamu yang baru datang. Karena pada prinsipnya industri hospitality, termasuk hotel, mengunggulkan servis sebagai salah satu added value, penyajian welcome drink merupakan wujud pelayanan yang pantas untuk diaplikasikan.

Dalam Good Practices Guide for Guesthouses and Small Hotels yang dipublikasikan ILO (International Labour Organization) dalam website-nya, penyajian welcome drink di hotel-hotel kecil dan guesthouse bisa menjadi salah satu cara promosi sederhana yang akan memberikan kesan postif bagi para tamu. Karena bukan merupakan mandatory, belum aturan baku dalam penyajian welcome drink, baik dari jenis minuman, porsi, dan cara penyajian. Pada prinsipnya, jenis minuman yang dipilih sebagai welcome drink adalah minuman yang menyegarkan karena penyajiannya sengaja diberikan sebagai minuman untuk mengatasi kelelahan para tamu. Selama ini, mocktail, cocktail, atau soft drink menjadi pilihan utama sebagai welcome drink. Pada beberapa hotel yang mengedepankan konsep heritage ataupun kearifan lokal budaya, minuman tradisional atau sentuhan bahan-bahan tradisional mulai banyak diperkenalkan sebagai welcome drink. Di Indonesia, Kunyit Asem dan Beras Kencur sudah diperkenalkan di beberapa hotel berbintang.

Dalam deskripsi singkat tentang Bir Pletok yang terdaftar dalam Warisan Budaya Tak Benda dari DKI Jakarta, tertulis bahwa nama 'pletok' diambil dari bunyi kapulaga (Amomumcompactum), salah satu rempah yang digodog dalam ramuan Bir Pletok, yang 'pecah' saat direbus sehingga menimbulkan bunyi mirip 'pletok'. Sementara istilah 'bir', konon merupakan istilah yang diambil Pitung, karena kerap melihat kebiasaan orang Belanda minum bir. Meskipun bisa dinikmati dalam keadaan panas, layaknya wedang, Bir Pletok kini lebih populer disajikan dalam keadaan dingin. Hasil wawancara dengan Heryus Saputro, pengamat budaya, aslinya
Bir Pletok disajikan panas karena es batu pertama kali dikenal di Jakarta pada tahun 1860-an dan mulai populer di awal tahun 1900-an, sedangkan ia meyakini bahwa sebagai minuman tradisional Betawi, Bir Pletok sudah lebih dulu lahir dari pada industri es batu. Konon, Bir Pletok dulunya memang dihidangkan di malam hari, saat musim penghujan, sebagai minuman penghangat bagi penduduk Betawi yang kala itu masih tinggal di pedalaman dalam lingkungan yang dingin (Sandy, 2014).

\section{METODOLOGI PENELITIAN}

Secara umum, penelitian ini bertujuan untuk memperoleh gambaran konsep pariwisata berbasis kuliner lokal khas Betawi, khususnya Bir Pletok. Sebagai produk wisata, serangkaian strategi dan promosi harus dipersiapkan agar minuman tradisional yang terbuat dari ekstrak rempah menyehatkan ini layak jadi duta yang mewakili kekayaan kuliner Betawi serta memiliki standar cita rasa yang konsisten dan mutu organoleptik yang optimal. Selain itu, penelitian ini juga dirancang untuk membuat deskripsi dan gambaran secara faktual dan akurat mengenai fakta-fakta sejarah/legenda/riwayat yang berhubungan dengan Bir Pletok sebagai salah satu kearifan lokal Betawi.

Untuk seleksi terhadap produsen Bir Pletok dilakukan pada 5 wilayah administratif. Melakukan survey terhadap wakil kelompok masyarakat Betawi dan menyebarkan kuisioner untuk mendapatkan 5 macam Bir Pletok yang mewakili wilayah Jakarta Timur, Jakarta Selatan, Jakarta Barat, Jakarta Pusat, dan Jakarta Utara. Adapun yang digunakan dengan melakukan wawancara, studi pustaka, dan observasi langsung untuk mendapatkan resep dari 5 macam Bir Pletok referensi. Sementara pemilihan Bir Pletok yang paling disuka dengan melakukan uji ranking terhadap 20 panelis semi terlatih untuk mendapatkan 3 rangking terbaik dari 5 Bir Pletok yang dijadikan sampel. Panelis merupakan mahasiswa dan tim pengajar dari STIP Triksati yang memiliki pengetahuan tentang 
Lila Muliani, Mempromosikan Bir Pletok Sebagai Minuman Khas Betawi Melalui Penyajian...

pengujian sensori dan atribut sensori. Tiap panelis diminta untuk memberikan peringkat urutan kesukaan dengan nilai 1 sampai 5. Sample yang paling disukai diberi ranking satu, yang disukai kedua diberi ranking 2 dan seterusnya. Tiga sampel yang terpilih selanjutnya disebut Bir Pletok terpilih.

Kemudian dilakukan uji hedonik terhadap 20 panelis semi terlatih untuk mendapatkan 1 Bir Pletok yang paling disuka dari 3 sampel Bir Pletok terpilih. Selanjutnya disebut sebagai Bir Pletok terpilih dan disukai. Tiap panelis diminta untuk memberikan penilaian dari 1 sampai 6 dengan kriteria (1) sangat tidak suka, (2) tidak suka, (3) agak tidak suka, (4) agak suka, (5) suka, dan (6) sangat suka. Tahap selanjutnya adalah pembakuan resep Bir Pletok terpilih dan disukai. Ini dapat dilakukan dengan uji coba sebanyak 3 kali untuk memastikan bahwa resep dan metode pembuatan yang telah dibakukan dapat menghasilkan rasa dan aroma yang tidak berbeda dengan Bir Pletok terpilih dan disukai. Dalam pembakuan resep Konsentrat Bir Pletok dan penyiapan welcome drink, adalah membakukan formula Konsentrat Bir Pletok dengan variasi pemekatan volume sebesar $1 / 4$ dan $1 / 8$, variasi waktu perebusan atau ekstraksi selama 20, 40, dan 60 menit. Dalam resep baku pembuatan konsentrat, gula sengaja tidak ditambahkan karena penyajian welcome drink dari Konsentrat Bir Pletok yang diharapkan adalah dengan menyandingkannya bersama sirop gula sehingga wisawatan bisa menambahkan gula sesuai dengan tingkat kesukaan. Wisatawan yang sedang diet gula pun bisa mengatur sendiri penambahan gula sesuai kebutuhannya.

Pengujian terakhir adalah tingkat penerimaan terhadap Bir Pletok sebagai welcome drink. Dilakukan dengan menyiapkan dan menyajikan Konsentrat Bir Pletok sebagai welcome drink kepada 80 orang panelis umum yang mewakili konsumen atau wisawatan secara umum. Pengujian ini dilakukan untuk melihat seberapa besar dukungan masyarakat terhadap penyajian Bir Pletok sebagai welcome drink. Oleh karena itu, secara paralel dilakukan wawancara terhadap sejarawan, budayawan, tokoh, dan praktisi kuliner Betawi untuk mendapatkan deskripsi dan gambaran tentang sejarah Bir Pletok. Adapun analisis data untuk menentukan Bir Pletok terpilih dan disukai dianalisis menggunakan ANOVA (Analisis Varians) pada tingkat kepercayaan 95\%, diikuti dengan uji Duncan (Duncan Multiple Range Test) untuk menentukan perbedaan nyata antarsampel. Aroma, rasa, warna, dan penilaian secara keseluruhan (overall) menjadi parameter yang dianalisis. Parameter ini merupakan atribut pangan yang berperan penting dalam menentukan penerimaan atau penolakan terhadap suatu makanan atau minuman oleh konsumen. Sedangkan data uji hedonik untuk menentukan tingkat kesukaan dan penerimaan terhadap Bir Pletok sebagai welcome drink dianalisis menggunakan metode One Sample T-Test.

\section{HASIL DAN PEMBAHASAN}

Penelitian ini terdiri dari 2 tahap, yaitu penelitian pendahuluan dan penelitian utama. Tahap penelitian pendahuluan diawali dengan melakukan observasi dan wawancara untuk menyeleksi beberapa variasi Bir Pletok dari produsen berbeda yang mewakili 5 wilayah administratif Jakarta, yaitu Jakarta Timur, Jakarta Barat, Jakarta Selatan, Jakarta Utara, dan Jakarta Pusat. Kemudian dilanjutkan dengan uji coba pengolahan Bir Pletok sesuai dengan formula dan metode yang sama dari produsen Bir Pletok yang terpilih dan disukai supaya didapatkan kualitas rasa dan aroma yang tidak berbeda.

Selanjutnya, pada penelitian utama dilakukan pembakuan formula dan teknik pengolahan Konsentrat Bir Pletok. Diawali dengan melakukan percobaan untuk mendapatkan volume pemekatan yang optimum. Selanjutnya adalah melakukan kombinasi terhadap dua variable, yaitu suhu dan waktu pengolahan, untuk mendapatkan formula paling optimum yang saat diencerkan kembali akan memberikan rasa, aroma, dan warna yang tidak berbeda dengan Bir Pletok terpilih dan disukai. Konsentrat Bir Pletok yang terpilih ini kemudian akan diujikan lagi untuk mendapatkan gambaran dari masyarakan umum terhadap penerimaannya dan dukungannya atas rencana penyajian Bir 
Pletok sebagai welcome drink sebagai bentuk promosi kuliner Betawi di Jakarta.

\section{A. Seleksi Bir Pletok di Jakarta}

Meski belum menjadi minuman populer yang terkenal sebagai ikon ibu kota Jakarta, produsen Bir Pletok dapat ditemukan secara 226sporadis, tersebar di berbagai wilayah Jakarta. Para produsen tersebut menjajakan Bir Pletok di rumah makan atau warung Betawi sederhana, atau melayani pemesanan untuk acara-acara besar atau perhelatan khusus komunitas Betawi di Jakarta dan wilayah sekeliling Jakarta (yang disebut Bodetabek, Bogor-Depok-Tangerang-Bekasi). Dari pengamatan yang dilakukan, ditemukan variasi dan keragaman dari tiap Bir Pletok yang ada. Keragaman terjadi pada semua aspek, baik bahan baku, cara produksi, kemasan, rasa, warna, dan aroma (Anonim, 2011). Untuk mendapatkan referensi produsen Bir Pletok mana yang akan diteliti dan dikembangkan lebih lanjut, perlu dilakukan observasi, baik dengan metode wawancara langsung atau dengan menggali informasi melalui media digital.

Wawancara dilakukan kepada beberapa tokoh Betawi, antara lain pengurus LKB (Lembaga Kebudayaan Betawi), pengurus Pusat Kebudayaan Betawi Setu Babakan, dan beberapa pemilik bisnis kuliner Betawi. Wawancara dilengkapi dengan survei berisi beberapa pertanyaan terbuka tentang Bir Pletok dan referensi dari para tokoh terhadap Bir Pletok yang diunggulkannya. Selanjutnya, dipilih 5 (lima) Bir Pletok dari semua referensi yang memiliki rasa dan aroma memenuhi kriteria standar Bir Pletok sebagai minuman herbal tradisional dan memiliki karakter yang kuat. Berikut Bir Pletok yang terpilih:

a. Bir Pletok Alifah dari Kedoya Selatan, Jakarta Barat.

b. Bir Pletok Warung None dari Kemayoran, Jakarta Pusat.

c. Bir Pletok Mpok Nini dari Bekasi (mewakili wilayah Jakarta Timur).

d. Bir Pletok Cempedak Lestari dari Jagakarsa, Jakarta Selatan.

e. Bir Pletok Siri Dare dari Warung Buncit, Jakarta Selatan.

Dari hasil yang didapat, tidak ditemukan referensi Bir Pletok dari wilayah Jakarta Utara. Sebaliknya, ada 2 perwakilan Bir Pletok dari Jakarta Selatan. Secara historis, pembangunan ibu kota secara besar-besaran di sekitar tahun 1970-an menyebabkan terjadinya migrasi penduduk Betawi dari tengah kota Jakarta ke pinggiran, termasuk ke selatan Jakarta, seperti Pasar Minggu dan Depok. Itu yang membuat jumlah etnis Betawi di wilayah ini cukup banyak, sehingga produsen Bir Pletok pun lebih mudah ditemui. Sedangkan di Jakarta Utara, komunitas etnis Betawi jumlahnya tergolong paling sedikit. Penduduk Betawi di Jakarta Utara terkonsentrasi di area Cilincing dan Marunda (Anonim, 2014). Jadi pantaslah jika selama observasi, tidak ditemukan produsen Bir Pletok dari wilayah Jakarta Utara.

Dari 5 (lima) sampel Pletok yang didapat, masing-masing memiliki keunikan yang berbeda-beda, baik dari warna, rasa, dan aroma. Perbedaan masing-masing karakter Bir Pletok dapat dilihat sebagai berikut: 
Lila Muliani, Mempromosikan Bir Pletok Sebagai Minuman Khas Betawi Melalui Penyajian...

Tabel. 1. Karakter Bir Pletok

\begin{tabular}{llll}
\hline Bir Pletok & Warna & Rasa & Aroma \\
\hline \hline Alifah & Merah-keunguan & $\begin{array}{l}\text { Pedas } \\
\text { berempah }\end{array}$ & Harum berempah \\
\hline Warung None & Merah-oranye & $\begin{array}{l}\text { Pedas } \\
\text { berempah }\end{array}$ & Harum berempah \\
\hline Mpok Nini & $\begin{array}{l}\text { Merah-cokelat } \\
\text { gelap }\end{array}$ & $\begin{array}{l}\text { Pedas } \\
\text { berempah } \\
\text { cenderung pahit }\end{array}$ & Harum berempah \\
\hline Cempedak Lestari & $\begin{array}{l}\text { Merah } \\
\text { kecokelatan }\end{array}$ & $\begin{array}{l}\text { Pedas } \\
\text { berempah }\end{array}$ & Harum berempah \\
\hline Siri Dare & $\begin{array}{l}\text { Merah } \\
\text { kecokelatan }\end{array}$ & $\begin{array}{l}\text { Pedas } \\
\text { berempah, } \\
\text { cenderung pahit }\end{array}$ & Harum berempah \\
\hline \hline
\end{tabular}

Dari kelima sampel Bir Pletok yang diujikan, selanjutnya dilakukan seleksi untuk memilih Bir Pletok yang paling disuka. Seleksi dilakukan dengan melakukan uji sensori secara 2 tahap. Tahap pertama dilakukan dengan metode Uji Rangking (dalam hal ini adalah Uji Ranking Kesukaan) dan tahap kedua menggunakan Uji Hedonik. Pengujian perlu dilakukan bertahap karena sampel yang digunakan jumlahnya relatif banyak.

Untuk hasil uji rangking, tiap panelis memberikan penilaiannya terhadap 5 sampel Bir Pletok berdasarkan peringkat kesukaannya, dari peringkat 1 hingga peringkat 5. Rata-rata hasil uji ranking ini dapat dilihat sebagai berikut:

Tabel 2. Hasil Uji Ranking Bir Pletok

\begin{tabular}{llll}
\hline Produsen & Cempedak lestari & Alifah & Siri Dare \\
\hline \hline Total & 38 & 64 & 68 \\
\hline Nilai rata-rata & 1,9 & 3,2 & 3,4 \\
\hline \hline
\end{tabular}

Analisis data dilakukan menggunakan metode rata-rata (mean). Sampel dengan nilai mean paling kecil merupakan sampel yang paling banyak dipilih sebagai peringkat 1 , dan seterusnya. Dapat dilihat bahwa tiga nilai mean terkecil yang menduduki peringkat 3 besar, adalah Bir Pletok Cempedak Lestari (peringkat 1), Warung None (peringkat 2), dan Alifah (peringkat 3).
Sementara untuk hasil uji hedonik, tiap panelis memberikan penilaiannya untuk memilih satu Bir Pletok yang paling disuka dari 3 Bir Pletok terpilih. Uji ini dilakukan untuk mengkonfirmasi hasil uji Rangking sebelumnya. Hasil uji hedonik dianalisis menggunakan metode Duncan, hasilnya adalah sebagai berikut: 
Tabel 3. Hasil Uji Hedonik

\begin{tabular}{lllll}
\hline & \multicolumn{4}{l}{ Nilai Kesukaan } \\
\cline { 2 - 5 } Bir Pletok & Rasa & Warna & Aroma & Keseluruhan \\
\hline Alifah & $2,7000 \mathrm{a}$ & $4,1000 \mathrm{a}$ & $3,1000 \mathrm{~b}$ & $3,3500 \mathrm{a}$ \\
\hline Warung None & $3,6500 \mathrm{~b}$ & $4,5000 \mathrm{a}$ & $4,0500 \mathrm{a}$ & $4,0000 \mathrm{a}$ \\
\hline $\begin{array}{l}\text { Cempedak } \\
\text { Lestari }\end{array}$ & $5,0500 \mathrm{c}$ & $4,2000 \mathrm{a}$ & $4,8000 \mathrm{a}$ & $4,9500 \mathrm{~b}$ \\
\hline
\end{tabular}

Hasil uji sensori menunjukkan bahwa tingkat kesukaan terhadap atribut rasa pada ketiga sampel Bir Pletok menunjukkan bahwa Bir Pletok Cempedak Lestari dengan nilai tertinggi (5.0500) adalah paling disukai dan berbeda nyata dengan Bir Pletok lainnya. Sedangkan tingkat kesukaan terhadap atribut warna, Bir Pletok Warung None dengan nilai tertinggi (4.5000) adalah paling disukai walau secara statistik nilanya tidak berbeda nyata. Untuk tingkat kesukaan terhadap atribut aroma, Bir Pletok Cempedak Lestari dengan nilai tertinggi (4.8000) adalah paling disukai namun secara statistik tidak berbeda nyata dengan Bir Pletok Warung None. Secara keseluruhan, Bir Pletok Cempedak Lestari adalah paling disukai dengan nilai tertinggi (4.9500) dan secara statistik berbeda nyata dengan Bir Pletok Warung None dan Bir Pletok Alifah. Dapat disimpulkan, dari hasil uji sensori dengan metode hedonik, Bir Pletok Cempedak Lestari merupakan Bir Pletok terpilih dan disukai yang selanjutnya akan dikembangkan lebih lanjut untuk menjadi Bir Pletok konsentat.

Bir Pletok Cempedak Lestari merupakan produsen Bir Pletok di bawah binaan Setu Babakan. Merupakan usaha yang dijalankan oleh sekelompok ibu-ibu PKK di Kampung Cempedak, Kelurahan Srengseng Sawah, Kecamatan Jagakarsa, Jakarta Selatan. Mereka adalah Ibu Hj Etih, Ibu Acih Sugianti, Ibu Ningsih, dan Ibu Ika Hartika, dan Ibu Suryati, yang secara kebetulan kelimanya masih memiliki hubungan persaudaraan. Usaha skala rumah tangga ini telah berjalan selama 8 tahun, berlokasi di bagian belakang rumah Ibu $\mathrm{Hj}$. Etih. Usaha keluarga ini menjadi salah satu UKM binaan Dinas
Pertanian DKI Jakarta karena itu proses produksinya sudah memiliki SOP yang baku dan standar keamanan pangan. Bir Pletok Cempedak Lestari sering kedatangan tamu dari Dinas Pertanian atau instansi pemerintah daerah lain yang ingin melakukan studi banding. Hingga saat ini Bir Pletok Cempedak Lestari tidak memiliki toko atau tempat khusus untuk berjualan, produksinya masih sebatas melayani pesanan yang secara rutin datang dari Setu Babakan dan rumah makan Betawi di sekitar wilayah Jagakarsa. Melalui teknik pemasaran word of mouth, kini jumlah pesanan Bir Pletok Cempedak Lestari semakin meningkat, keluar dari area Jagakarsa.

\section{B. Pembuatan Konsentrat Bir Pletok}

1. Teknik Pengolahan Bir Pletok

Bahan-bahan berupan rempah yang dibutuhkan untuk membuat Bir Pletok terdiri dari 12 jenis rempah yang terdiri dari 4 jenis rempah segar, yaitu jahe, serai, daun pandan, dan daun jeruk, serta 8 jenis rempah kering, yaitu kayumanis, cengkih, kayu mesoji, kapulaga, merica, biji pala, cabe jawa, dan kayu secang. Gula yang digunakan adalah gula pasir. Penambahan garam, meski dalam jumlah kecil, berkontribusi membuat rasa manis menjadi semakin 'bulat'.

Jahe merupakan bahan utama yang digunakan dalam porsi paling besar dalam formulasi Bir Pletok. Rempah ini jugalah yang memberikan kontribusi paling besar terhadap sensasi khas rasa pedas dan hangat pada Bir Pletok. Dalam formulasi yang digunakan, dibutuhkan 2 jenis jahe, yaitu jahe gajah dan jahe emprit dengan rasio 1: 1. Jahe gajah berukuran besar, memiliki kadar air 
Lila Muliani, Mempromosikan Bir Pletok Sebagai Minuman Khas Betawi Melalui Penyajian...

tinggi, 'daging' berwarna kuning muda, 229 memberi rasa pedas yang sedang, dan merupakan jenis jahe yang umum digunakan untuk memasak. Jahe emprit berukuran kecil, kadar air relatif lebih rendah, 'daging' berwarna kuning keabu-abuan, berserat, dan memiliki rasa pedas yang dominan.

Rasio 1:1 merupakan jumlah yang paling tepat untuk dapat menghasilkan cita rasa Bir Pletok yang sesuai. Terlalu banyak jahe emprit akan memberikan rasa pedas yang cenderung pahit. Sedangkan jika jahe gajah yang lebih banyak, rasa pedasnya jadi terasa kurang. Proses pengolahan diawali dengan proses penyortiran bahan. Gunakan rempah yang berkualitas baik untuk mendapatkan rasa dana aroma yang optimum. Rempah-rempah segar dipilih yang masih fresh, tidak kering dan tidak busuk. Rempah-rempah kering dipilih yang bersih, utuh, dan tidak berjamur. Kemudian semua bahan dicuci hingga bersih di bawah air mengalir. Khusus untuk jahe, bagian kulit harus dipastikan bersih dari sisasisa kotoran dan tanah yang terselip.

Dalam pengolahan, kedua jenis jahe yang digunakan tidak perlu dikupas terlebih dahulu. Cukup disikat dan dicuci bersih di bawah air mengalir. Selain memberikan dampak positif dari sisi ekonomi (lebih praktis dan tidak banyak bagian yang dibuang), bagian bawah kulit jahe ternyata mengandung lebih banyak minyak atsiri (komponen volatil oil atau minyak menguap) dibanding pada bagian tengahnya (Yenita, 2010). Mengolah jahe bersama bagian kulitnya akan membuat rasa dan aroma jahe menjadi lebih pekat. Sebelum proses perebusan, dilakukan proses pengecilan ukuran terhadap semua rempah yang digunakan. Tujuannya adalah meningkatkan volume dan luas permukaan untuk memaksimalkan ekstraksi dari komponenkomponen yang terkandung dalam rempah. Proses pengecilan ukuran dapat dilakukan dengan cara dimemarkan, diiris/dipotong, atau diparut. Dalam pembuatan Bir Pletok Cempedak Lestari, metode pengecilan ukuran yang digunakan adalah diiris/dipotong (untuk jahe, daun pandan, dan daun jeruk) dan dimemarkan (untuk rempah lainnya, termasuk rempah kering). Total padatan tidak terlarut pada minuman ekstrak jahe cenderung meningkat dengan metode pengecilan ukuran diparut (Mayani, 2014).

Dengan diparut, komponen serat pada jahe semakin banyak yang terekstrak sehingga padatan yang tidak terlarut jadi semakin tinggi sehingga ekstrak jahe jadi terlihat lebih keruh. Penambahan kayu secang sebagai pewarna dilakukan di akhir proses pengolahan. Sebelum memasukkan kayu secang, rempah-rempah lainnya ditiriskan terlebih dahulu agar warnanya tidak ikut terserap oleh rempah-rempah tersebut. Dalam metode pembuatan Bir Pletok Cempedak Lestari, kayu secang cukup direbus selama 5 menit untuk mendapatkan warna yang diharapkan. Lama ekstraksi kayu secang ini sesuai dengan SOP (Standard Operation Procedure) Pembuatan Bir Pletok yang dikeluarkan oleh Balai Pengkajian Teknologi Pertanian Jakarta (Anonim, 2011).

Jumlah kayu secang yang ditambahkan dalam formula pembuatan Bir Pletok Cempedak Lestari relatif banyak, yaitu $200 \mathrm{~g}$ untuk $11 \mathrm{~L}$ air. Padahal jumlah yang disarankan oleh Balai Pengkajian Teknologi Pertanian Jakarta adalah $50 \mathrm{~g}$ untuk $10 \mathrm{~L}$ air. Perbedaan jumlah kayu secang ini membuat warna Bir Pletok Cempedak Lestari cenderung merah kecokelatan, bukan merah keunguan. Warna kecokelatan yang dihasilkan dalam ekstrak kayu secang berasal dari senyawa tanin yang kadarnya cukup tinggi dalam kulit kayu secang, yaitu sekitar 44\% (Anonim, 2012). Proses penyaringan berperan cukup penting dalam menentukan penampakan atau tampilan Bir Pletok yang dihasilkan karena kekeruhan akan memberikan kesan kotor. Karena itu sedapat mungkin Bir Pletok yang dihasilkan terlihat jernih dan mengandung sesedikit mungkin endapan.

Komponen tak larut air dari hasil ekstraksi atau perebusan rempah-rempah menghasilkan endapan halus yang memerlukan penggunaan saringan khusus. Saringan yang digunakan adalah kain monyl tipe T25. Kain ini merupakan kain saring/screen yang biasa digunakan dalam industri sablon. Proses pengecilan ukuran rempah yang semakin halus akan 
meningkatkan luas permukaan rempah yang terekstrak dan menghasilkan komponen tidak larut air yang semakin tinggi sehingga endapan semakin banyak dan penampilannya menjadi semakin keruh (Mayani, 2014).

2. Pembuatan Konsentrat Bir Pletok dan penyiapan welcome drink

Persiapan konsentrat Bir Pletok. Proses pemekatan untuk menghasilkan Konsentrat Bir Pletok dilakukan dengan metode sederhana, bukan dengan penggunaan evaporator, karena tujuannya adalah agar mudah diaplikasikan oleh industri skala rumah tangga. Teknik pemekatan yang dilakukan adalah dengan mengurangi volume air dan mendapatkan waktu ekstraksi terbaik. Volume air dikurangi hingga mencapai jumlah yang tepat untuk tetap dapat mengekstrak rempah-rempah secara optimum. Demikian juga dengan waktu ekstraksinya yang harus disesuaikan untuk mendapatkan kualitas ekstrak yang optimum. Tahapan ini diawali dengan percobaan pendahuluan untuk mengetahui seberapa banyak volume air yang bisa dikurangi secara optimum untuk membuat Konsentrat Bir Pletok. Kemudian dilanjutkan dengan menentukan waktu perebusan atau ekstraksi yang paling optimum.

Percobaan dilakukan dengan melakukan pemekatan volume air sebesar 1/4 dan 1/8 dari volume air standar. Dari hasil percobaan, pemekatan yang terpilih adalah pemekatan volume sebesar 1/4. Artinya, jumlah rempah yang digunakan adalah sebanyak 1 resep, tetapi volume air yang digunakan adalah 1/4 resep. Pada pemekatan volume sebesar 1/4, jumlah air masih cukup untuk merebus semua rempah dalam keadaan terendam. Sedangkan pemekatan volume sebesar $1 / 8$, jumlah airnya tidak cukup untuk merebus semua rempah dalam keadaan terendam, mengingat komposisi rempah yang digunakan cukup banyak dan bulky. Selain itu, jumlah pelarut menentukan kualitas hasil ekstraksi yang dihasilkan. Jumlah pelarut harus mampu mendistribusikan penyebaran partikel dalam pelarut selama proses ekstraksi sehingga permukaan kontak antara pelarut dan komponen yang akan dilarutkan menjadi semakin luas.

Jumlah pelarut yang terlalu sedikit akan mengurangi gradien konsentrasi sehingga mempercepat terjadinya kondisi kesetimbangan konsentrasi (Sridianti, 2015). Kondisi kesesetimbangan konsentrasi ini disebut juga kondisi jenuh. Dan proses ekstraksi dinyatakan selesai. Artinya, semakin kecil volume air yang digunakan bukan berarti semakin pekat konsentrat yang akan dihasilkan. Variabel lain yang diuji dalam pembuatan Konsentrat Bir Pletok adalah waktu perebusan rempah atau waktu kontak antara pelarut (dalam hal ini air) dengan partikel solid (dalam hal ini rempah-rempah) selama proses ekstraksi berlangsung. Tujuannya adalah untuk mendapatkan waktu perebusan yang paling optimum untuk menghasilkan Konsentrat Bir Pletok dengan kualitas yang tidak berbeda dengan Bir Pletok Cempedak Lestari sebagai Bir Pletok terpilih dan disukai. Mengacu pada resep baku pembuatan Bir Pletok pada Gambar 2 yang membutuhkan waktu selama 30 menit, maka percobaan dilakukan dengan variasi waktu 20 , 40, dan 60 menit. Ukuran partikel dan suhu perebusan atau ekstraksi merupakan faktor lain yang mempengaruhi proses ekstraksi padat-cair. Namun dalam penelitian ini kedua variabel tersebut dianggap sama dan tidak diperhitungkan.

Penyiapan welcome drink. Untuk menyiapkan Konsentrat Bir Pletok menjadi welcome drink diperlukan penelitian lanjutan untuk mendapatkan tingkat pengenceran yang memiliki rasa, aroma, dan warna yang tidak berbeda dengan Bir Pletok Cempedak Lestari sebagai Bir Pletok terpilih dan disukai. Variasi tingkat pengenceran yang dilakukan adalah 4, 5, dan 6 kali sehingga seperti tertulis pada tabel dibawah ini akan didapat 9 kombinasi Konsentrat Bir Pletok, yaitu A1, A2, A3, A4, A5, A6, A7, A8, A9. 
Lila Muliani, Mempromosikan Bir Pletok Sebagai Minuman Khas Betawi Melalui Penyajian...

Tabel 4. Variasi tingkat pengenceran Bir Pletok

\begin{tabular}{llll}
\hline \multirow{2}{*}{ Pengenceran } & \multicolumn{3}{l}{ Waktu perebusan (menit) } \\
\cline { 2 - 4 } & 20 & 40 & 60 \\
\hline \hline $4 x$ & A1 & A2 & A3 \\
$5 x$ & A4 & A5 & A6 \\
$6 x$ & A7 & A8 & A9 \\
\hline
\end{tabular}

Selanjutnya terhadap 9 kombinasi tersebut dilakukan Uji Paired Comparison untuk mendapatkan 1 kombinasi yang dinyatakan tidak berbeda dari Bir Pletok Cempedak Lestari sebagai kontrol. Panelis untuk uji paired comparison adalah 4 orang ibu-ibu produsen Bir Pletok Cempedak Lestari yang termasuk kategori panelis terlatih karena mereka memiliki kepekaan yang sangat tinggi dan memahami secara mendalam karakter rasa, aroma, dan warna Bir Pletok Cempedak Lestari yang digunakan sebagai kontrol. Hasil uji paired comparison dapat dilihat pada tabel di bawah ini. Dari hasil uji paired comparison, semua panelis terlatih memilih sampel A6 sebagai sampel yang tidak berbeda dengan kontrol. Sampel A6 merupakan sampel Konsentrat Bir Pletok dengan kombinasi waktu perebusan 60 menit dan pengenceran sebesar 5 kali.

Tabel 5. Hasil Uji Paired Comparison

\begin{tabular}{lllll}
\hline \multirow{2}{*}{ Sampel } & \multicolumn{2}{l}{ Panelis } & & \\
\cline { 2 - 5 } & 1 & 2 & 3 & 4 \\
\hline \hline A1 & 1 & 1 & 1 & 1 \\
\hline A2 & 1 & 1 & 1 & 1 \\
\hline A3 & 1 & 1 & 1 & 1 \\
\hline A4 & 1 & 1 & 1 & 1 \\
\hline A5 & 1 & 1 & 1 & 1 \\
\hline A6 & 0 & 0 & 0 & 0 \\
\hline A7 & 1 & 1 & 1 & 1 \\
\hline A8 & 1 & 1 & 1 & 1 \\
\hline A9 & 1 & 1 & 1 & 1 \\
\hline Kerangany
\end{tabular}

Keterangan:

0 : sama

1: berbeda

Dalam penyiapan welcome drink, pengenceran 5 kali artinya adalah dibutuhkan sebanyak $100 \mathrm{ml}$ Konsentrat Bir Pletok dan $400 \mathrm{ml}$ air untuk menghasilkan $500 \mathrm{ml}$ welcome drink Bir Pletok. Dan untuk memberikan rasa manis yang pas, direkomendasikan untuk menambahkan 200 $\mathrm{ml}$ sirop gula untuk tiap $1 \mathrm{~L}$ welcome drink Bir Pletok. Pada aplikasinya, jumlah penambahan gula untuk penyajian welcome drink Bir Pletok bisa disesuaikan dengan tingkat kesukaan atau kebutuhan tiap orang. Tetapi, berdasarkan percobaan yang dilakukan, rasa manis bersinergi dengan rasa pedas dari rempah pada Bir Pletok. Jika rasa manisnya kurang, maka rasa pedas rempah pun terasa kurang tajam. Dan begitu pun sebaliknya. Pengenceran 5 kali cukup efektif dan efisien dalam memberikan kepraktisan kepada pihak hotel ataupun restoran untuk menyiapkan dan menyimpan Konsentrat Bir Pletok yang akan disajikan sebagai welcome drink.

3. Dukungan masyarakat terhadap welcome drink Bir Pletok.

Selama ini, jenis minuman untuk welcome drink yang umumnya disajikan 
pilihannya adalah mocktail, jus, soft drink untuk hotel dan beberapa jenis minuman beralkohol, seperti cocktail, untuk bar atau kafe. Beberapa tahun belakangan, saat tren local cuisine dan apresiasi terhadap kearifan lokal kian tinggi, minuman tradisional seperti Kunyit Asem, Temulawak, atau Beras Kencur sudah mulai dipromosikan sebagai welcome drink pada hotel-hotel berbintang yang mengedepankan konsep heritage of Indonesia. Minuman ini disajikan dalam tampilan yang cantik dalam kondisi dingin. Penyajian Bir Pletok sebagai welcome drink tak sematamata hanya untuk mempromosikan kekayaan kuliner Betawi kepada para wisatawan. Selain menyegarkan, kandungan senyawa bioaktif yang ada dalam tiap rempah yang digunakan, akan memberikan khasiat yang baik untuk kesehatan dan kebugaran.

Untuk mengetahui dukungan masyarakat terhadap penyajian Bir Pletok sebagai welcome drink, dilakukan uji sensori lanjutan. Bentuk dukungan tersebut diukur melalui seberapa banyak panelis yang setuju jika Bir Pletok dijadikan welcome drink. Pengujian dilakukan terhadap 80 panelis, mewakili masyarakat umum dan wisatawan. Para panelis juga dimintai penilaian hedonik terhadap rasa, aroma, warna dan keseluruhan (overall) Bir Pletok yang disajikan. Bir Pletok disajikan dalam keadaan dingin untuk memberi kesan menyegarkan. Hasil pengujian dapat dilihat pada tabel berikut ini:

Tabel 6. Hasil Pengujian Bir Pletok dijadikan welcome drink

\begin{tabular}{|c|c|c|c|c|c|c|}
\hline \multicolumn{7}{|c|}{ One-Sample Test } \\
\hline & \multicolumn{6}{|c|}{ Test Value $=0$} \\
\hline & \multirow[b]{2}{*}{$\mathrm{t}$} & \multirow[b]{2}{*}{ Df } & \multirow{2}{*}{$\begin{array}{l}\text { Sig. }(2- \\
\text { tailed) }\end{array}$} & \multirow{2}{*}{$\begin{array}{l}\text { Mean } \\
\text { Difference }\end{array}$} & \multicolumn{2}{|c|}{$\begin{array}{l}\text { 95\% Confidence Interval of the } \\
\text { Difference }\end{array}$} \\
\hline & & & & & Lower & Upper \\
\hline Aroma & 55,507 & 79 & ,000 & 2,92500 & 2,8201 & 3,0299 \\
\hline Rasa & 52,011 & 79 &, 000 & 3,23750 & 3,1136 & 3,3614 \\
\hline Warna & 38,743 & 79 &, 000 & 2,85000 & 2,7036 & 2,9964 \\
\hline Overall & 59,599 & 79 &, 000 & 3,06250 & 2,9602 & 3,1648 \\
\hline welcome.drink & 52,769 & 79 &, 000 & 3,11250 & 2,9951 & 3,2299 \\
\hline
\end{tabular}

Penilaian kesukaan atau hedonik dilakukan menggunakan 4 kriteria, yaitu 1: sangat tidak suka, 2: tidak suka, 3: suka, dan 4: sangat tidak suka. Penerimaan terhadap Bir Pletok sebagai welcome drink juga dilakukan dengan 4 kriteria, yaitu 1: sangat tidak setuju, 2: tidak setuju, 3: setuju, dan 4: sangat setuju. Data pengujian dianalisis menggunakan metode One Sample T-Test yang merupakan salah satu jenis uji hipotesis, yaitu cabang ilmu statistik yang dipergunakan untuk menguji kebenaran suatu pernyataan secara 232statistik dan menarik kesimpulan apakah menerima atau menolak pernyataan tersebut. Uji Hipotesis juga dapat memberikan kepercayaan diri dalam pengambilan keputusan yang bersifat objektif (Kho, 2015).
Dalam pengujian ini, hipotesa atau dugaan atau kesimpulan sementara yang diharapkan adalah Bir Pletok dapat diterima sebagai welcome drink. Sebagai dugaan atau kesimpulan sementara, pernyataan ini disebut $\mathrm{H} 1$ atau $\mathrm{Ha}$ (Hipotesis alternatif) atau $\mathrm{Hk}$ (Hipotesis kerja). Berarti, pernyataan $\mathrm{H} 0$ adalah Bir Pletok belum dapat diterima sebagai welcome drink.

Data penerimaan Bir Pletok sebagai welcome drink pada Tabel 4.5 menunjukkan bahwa karena nilai $t$ hitung $(52,769)>t$ tabel $(1,99045)$ dan $\mathrm{p}=0.0000<0.005$ maka keputusannya adalah $\mathrm{H} 0$ ditolak, H1 diterima. Maka kesimpulannya adalah Bir Pletok dapat diterima sebagai welcome drink. Jika data dianalisis menggunakan metode rata-rata, 
Lila Muliani, Mempromosikan Bir Pletok Sebagai Minuman Khas Betawi Melalui Penyajian...

maka dapat disimpulkan bahwa secara keseluruhan (overall) Bir Pletok disukai (nilai rata-rata 3,06250) dan penyajian Bir Pletok sebagai welcome drink disetujui (nilai ratarata 3,11250$)$.

\section{PENUTUP}

Hasil penelitian menunjukkan bahwa Bir Pletok sebagai bagian dari kekayaan kuliner Betawi mendapat dukungan dan apresiasi positif jika disajikan sebagai welcome drink. Pembuatan Konsentrat Bir Pletok menjadi salah satu cara yang dapat mempermudah penyimpanan dan penyajiannya sehingga lebih praktis dan efisien. Pembuatan konsentrat dengan pemekatan volume sebesar 1/4 kali dan waktu perebusan selama 60 menit dalam skala penelitian (1/2 resep), terbukti dapat menghasilkan Konsentrat Bir Pletok dengan kualitas rasa dan aroma yang tidak berbeda dari Bir Pletok segar yang tanpa pemekatan.

Berdasarkan hasil penelitian yang sudah dilakukan, ada beberapa keterbatasan yang bisa menjadi saran untuk pengembangan lebih lanjut, yaitu:

1. Pembuatan Konsentrat Bir Pletok dalam skala yang lebih besar.

2. Evaluasi umur simpan Konsentrat Bir Pletok.

3. Agar predikat Bir Pletok sebagai minuman herbal yang sehat dapat lebih diterima semua kalangan, termasuk orang-orang yang harus diet gula dan kalori karena alasan kesehatan, dapat dicoba menambahkan pemanis alami nol kalori, misal Stevia yang berasal dari ekstrak tanaman stevia.

4. Untuk menyiasati perbedaan tingkat penerimaan terhadap rasa manis yang berbeda-beda pada tiap orang, dapat digunakan rujukan pustaka tentang threshold atau ambang batas maksimal yang dapat diterima terhadap tingkat rasa manis.

5. Untuk dapat mengimplementasikan usulan penyajian Bir Pletok sebagai welcome drink dalam industri hospitality di Jakarta, peran serta pemerintah daerah provinsi DKI Jakarta sangatlah dibutuhkan.

\section{DAFTAR PUSTAKA}

Acandra. (2010). Cengkeh "Super Food" Baru. Melalui: $<$ http://female.kompas.com/read/2010/03 /19/10230731/cengkeh.superfood.baru> [ 07/05/15].

Adi, W.,\& Permanasari, I. (2013). Kala Beragam Makanan Bertempur. Melalui: <http://travel.kompas.com/read/2013/07/ $\underline{16 / 0812158 / \text { Kala.Beragam.Makanan.Bert }}$ empur $>[07 / 20 / 15]$.

Anonim. (2006). Pengujian Organoleptik (Evaluasi Sensori) dalam Industri Pangan. Melalui:

$<$ http://tekpan.unimus.ac.id/wpcontent/uploads/2013/07/PengujianOrganoleptik-dalam-Industri-Pangan.pdf $\geq[08 / 19 / 15]$.

Anonim. (2011). Standarisasi Mutu Bir Pletok. Melalui: <http://jakarta.litbang.pertanian.go.id/ind/ index.php?option=com_content $\&$ view $=\mathrm{ar}$ ticle\&id=29:standarisasi-mutu-birpletok\&catid=43: bir-pletok\&Itemid $=43>$ [07/26/15].

Anonim. (2014). Penyebaran Penduduk Betawi di Wilayah Jakarta Utara. Melalui:

$<$ http://jakartapedia.bpadjakarta.net/index .php/Penyebaran_Penduduk_Betawi_di Wilayah_Jakarta_Utara $>$ [08/19/15].

Blakey, Christina. (2012). Consuming Place: Tourism's Gastronomy Connection. University of Hawai' $i$ at Hilo · Hawai'i Community College, p.52.

Bustan, M.D, Febriayani, R., dan Pakpahan, H. (2008). Pengaruh Waktu Ekstraksi dan Ukuran Partikel Terhadap Berat Oleoresin Jahe yang Diperoleh dalam Berbagai Jumlah Pelarut Organik (Methanol).Jurnal Teknik Kimia, No. 4, Volume: 15.

Daneswari, Prita. (2014). Kuliner, Faktor Utama Wisatawan Indonesia Tentukan Melalui:

http://microsite.metrotvnews.com/lifestyl e/read/2014/02/19/912/217137/Kuliner- 
ISSN 1411-0830

Faktor-Utama-Wisatawan-Indonesia-

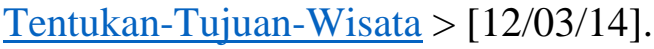

Dara, T.T. (2014). Delapan Manfaat Besar Kayu Manis. Melalui: $<$ http://rona.metrotvnews.com/read/2014/ 09/23/295425/8-manfaat-besar-kayumanis $>[07 / 05 / 15]$.

Deny, Septian. (2014). Jakarta Makin Banyak Disambingi Wisatawan. Melalui: <http://bisnis.liputan6.com/read/789463/i akarta-makin-banyak-disambangiwisatawan> [12/05/14].

Dewoto, H.R. (2007). Pengembangan Obat Tradisional Indonesia Menjadi Fitofarmaka. Majalah Kedokteran Indonesia, Volume: 57, Nomor 7.

Edward Inskeep. (1991). Tourism Planning, An Integrated and Sustainable Development Approach, Van Nostrand Reinhold, NewYork, p.286

Hermawan. (2014). Tiga Daerah Penyumbang Turis Asing Terbesar. Melalui: <http://www.portalkbr.com/berita/nasion al/3367620_4202.html> [12/20/14]

Karim, Shahrim AB. (2006). Culinary Tourism As A Destination Attraction: An Empirical Examination of The Destination's Food Image and Information Sources. Dissertation Report. Faculty of the Graduate College of the Oklahoma State University.

Kho, Dickson. (2015). Pengertian Uji Hipotesis dan Jenis-jenisnya. Melalui: $<$ http://teknikelektronika.com/pengertianuji-hipotesis-jenis-jenisnya/> $[08 / 30 / 15]$.

Koswara, S. (2009). Jahe, Rimpang dengan Sejuta Khasiat. Melalui: $<$ https://minyakatsiriindonesia.wordpress. com/atsiri-jahe/sutrisnokoswara $>[07 / 05 / 15]$.

Lestari A.J. dan Robi, H. (2013). Evaluasi Sensori Uji Ranking. Laporan Praktikum, Fakultas Pertanian, Universitas Jenderal Soedirman. Purwokerto.
Mayani, L., Yuwono, S.S., Ningtyas, D.W. (2014). Pengaruh Pengecilan Ukuran Jahe dan Rasio Air Terhadap Sifat Fisik Kimia dan Organoleptik Pada Pembuatan Sari Jahe (Zingiber officinale). Jurnal Pangan dan Agroindustri Vol. 2 No 4 p.148-158.

Moeloek, N., dkk. (2010). Uji Klinik Ekstrak Cabe Jawa (Piper retrofractum Vahl) sebagai Fitofarmaka Androgenik pada Laki-laki Hipogonad. Majalah Kedokteran Indonesia, Volume: 60, Nomor: 6.

Murdijati-Gardjito. (2013). Bumbu, Penyedap, dan Penyerta Masakan Indonesia. Gramedia Pustaka Utama, Jakarta.

Murdijati-Gardjito. (2014). Gastronomy Indonesia: The World of Wellness and Enjoyment. Pidato Dies Natalis STP Trisakti.

Nastiti, P.T., (2012). Jeruk Purut Segarkan Badan Lelah. Melalui: $<$ http://www.solopos.com/2012/08/24/tip s-herbal-jeruk-purut-segarkan-badanlelah-321536> [07/05/15]

Nursalikah, A. (2015). Delegasi KAA Ternyata Gemar Minum Jamu. Melalui: $<$ http://www.republika.co.id/berita/nasion al/umum/15/04/24/nnbjfq-delegasi-kaaternyata-gemar-minum-jamu $>[08 / 28 / 15]$

Padmaningrum, R.T., Marwati, S., dan Wiyarsi, A. (2012). Karakter Ekstrak Zat Warna Kayu Secang (Caesalpinia Sappan L.) sebagai Indikator Titrasi Asam Basa. Prosiding Seminar Nasional Penelitian, Pendidikan, dan Penerapan MIPA, Fakultas MIPA, Universitas Negeri Yogyakarta. Yogyakarta.

Panjaitan, R. H. (2005). Faktor-Faktor yang Mempengaruhi Volume Pemasaran Bir Pletok (Studi Kasus di Kelompok Usaha Ayu Lestari, Kelurahan Srengseng Sawah, Kecamatan Jagakarsa, Kotamadya Jakarta Selatan). Fakultas Pertanian, Universitas Nasional. Jakarta. 
Lila Muliani, Mempromosikan Bir Pletok Sebagai Minuman Khas Betawi Melalui Penyajian...

Purwaningsih, E.H. (2013). Jamu, Obat Tradisional Asli Indonesia:Pasang Surut Pemanfaatannya di Indonesia. Departemen Ilmu Kedokteran Komunitas Fakultas Kedokteran Universitas Indonesia, Jakarta.

Rahmawati, F. (2011). Kajian Potensi "Wedang Uwuh" sebagai Minuman Fungsional. Seminar Nasional Wonderful Indonesia. Jurusan Pendidikan Teknik Boga dan Busana, Universitas Negeri Yogyakarta. Yogyakarta.

Reza, Alberto. (2014).The Role of Local Food in the Touristic Experience. Bachelor's thesis Degree Programme International Business. Tampere University of Applied Science.

Risfaheri. (2012). Diversifikasi Produk Lada (Piper ningrum) Untuk Peningkatan Nilau Tambah. Buletin Teknologi Pascananen Pertanian Vol 8 (1). Balai Pengkajian Teknologi Pertanian. BangkaBelitung.

Rudi, A. (2015). Minimarket di Jakarta Akan Diwajibkan Jual Bir Pletok dan Nasi Uduk. Melalui $<$ http://megapolitan.kompas.com/read/20 15/01/09/15010331/Minimarket.di.Jakart a.Akan.Diwajibkan.Jual.Bir.Pletok.dan.N asi.Uduk> [07/04/15]

Sandy, G. (2014). Melestarikan Bir Pletok dan Gecok Jantung Pisang. Melalui: $<$ http://www.kompasiana.com/gapeysandy/melestarikan-bir-pletok-dan-gecokjantung-

pisang 54f3ab657455137c2b6c7d89> [06/16/15].

Shahab, Yasmine Zaki. (2004). Identitas dan Otoritas: Rekonstruksi Tradisi Betawi. Depok: Laboratorium Antropologi, FISIP UI.

Sommer, A.K. (2011). Fresh Lemongrass Field in Israel Become Mecca for Cancer Patients. Melalui: $<$ http://www.greentokri.com/lemongrass. pdf $>[07 / 05 / 15]$

Sugiyanto, Raisatun Nisa, dkk. (2013). Aplikasi Kayu Secang (Caesalpinia
Sappan L.) dalam Upaya Prevensi Kerusakan DNA Akibat Paparan Zat Potensial Karsinogenik Melalui MNPCE Assay. Program Studi Farmasi, Fakultas Farmasi, Universitas Gadjah Mada. Yogyakarta.

Sridianti. (2015). Pengertian Difusi dan Faktor yang Mempengaruhinya. Melalui: $<$ http://www.sridianti.com/pengertiandifusi-dan-faktor-yangmempengaruhinya.html $>[08 / 29 / 15]$.

Syafputri, Ella. (2012). Indonesia salah satu laboratorium tanaman obat dunia. Melalui:

<http://www.antaranews.com/berita/3009 97/indonesia-salah-satu-laboratoriumtanaman-obat-dunia $>[01 / 05 / 15]$.

Syamsir, E. 2011. Penanganan Bumbu dan Rempah. Majalah Kulinologi Indonesia, edisi 7.

Syarifani. (2015). DI KAA Putri Indonesia Bagi-Bagi Jamu. Melalui: <http://nasional.tempo.co/read/news/201 5/04/21/078659514/di-kaa-puteriindonesia-bagi-bagi-jamu $>[08 / 27 / 15]$.

Utami, Sri. (2013). Pengaruh Strategi Nation Branding "Wonderful Indonesia" Terhadap Proses Keputusan Berkunjung Wisatawan Australia ke Indonesia, Universitas Pendidikan Indonesia. Bandung.

Widjono, R.H. (2013). Sejarah adalah Guru Kehidupan dan Pesan dari Masa Silam. Melalui:

<http://www.kompasiana.com/nomaden/s ejarah-adalah-guru-kehidupan-dan-pesandari-masasilam_55287f98f17e6133558b45e7 (28> [08/15/15]

Yenita. (2010). Pengaruh Pemberian Ekstrak Jahe (Zingiber Officinale rocs.) terhadap Kadar Malondialdehid (MDA) Ginjal dan Gambaran Histopatologis Tubulus Proksimal Ginjal Mencit yang Diberi Plumbum Asetat. Tesis. Program Studi Magister Ilmu Biomedik, Fakultas Kedokteran, Universitas Sumatera Utara. Medan. 